\title{
Considerations Concerning the Oldest Stands from Banatului Mountains, Romania
}

\author{
Voichița Timiş-Gânsac ${ }^{1}$, Lucian Dincă ${ }^{2}$ \& Gabriel Cheregi ${ }^{1}$ \\ ${ }^{1}$ University of Oradea, Faculty of Environmental Protection, 26 Gen. Magheru Street, Oradea-410048, Romania \\ ${ }^{2}$ Marin Drăcea" National Institute for Research and Development in Forestry (INCDS), 13 Cloșca Street, Braşov- \\ 500040, Romania \\ Correspondence: Voichița Timiș - Gânsac, University of Oradea, Faculty of Environmental Protection, Oradea, \\ Romania. Tel: 40-745-678-316. E-mail: timisvoichita@yahoo.com
}

Received: May 24, 2020 Accepted: June 15, 2020 Online Published: June 30, 2020

\begin{abstract}
The present study was realized in Banatului Mountains (Romanian Carpathians) within Nera, Caransebeș and Băile Herculane Forest Districts, based on forest management plans from 1991-2008 and has led to the identification of 394 stand elements older than 200 years. The purpose of this paper was to analyze the trees' main qualitative characteristics (age), the stands' structural characteristics (consistency, composition, average diameter and average height) as well as the stational characteristics (altitude, slope, soil type). The main focus was to identify the oldest stands from Banatului Mountains.

The present paper presents the oldest 18 stands as well as their most representative characteristics: diameter, height, consistency, slope, altitude, soil, site and structure. The oldest stand identified in this area is a 260-year-old common beech stand from Nera with heights between 36-38 meters and a diameter of 98 meters. Furthermore, it has been observed that common beech stands have a normal consistency, while their structure is relatively unevenage. The research has shown that the surface occupied by old common beech stands that have reached their exploitability age is of 60.978 ha, namely $13 \%$ of the total surface of these forests. The site conditions where they are spread are characterised by preponderantly Northeast and South-West expositions, fields with slopes of 21-30 degrees, average altitudes of 900-1000 m, eutric cambisol and luvisol soils and medium and superior reliability sites.
\end{abstract}

Keywords: forest management plans, stands, exposition, slope, soil, site

\section{Introduction}

Common beech stands represent a natural vegetation for the majority of Central and West Europe, occupying approximately $65 \%$ of its total surface. The surface of forests from Europe has known a decrease caused by grazing and agriculture, followed by population growth and the apparition of urban agglomerations and industrial areas. Despite of this fact, common beech remains the most widespread broad-leaved species from Europe, being present in approximately $10 \%$ of European forests (excluding the Russian Federation).

Common beech is one of the most important broad-leaved species from Europe. Common beech forests can be found in the entire Carpathian chain, starting from low hills up to the mountain region, between $300-1400 \mathrm{~m}$ altitudes. In Romania, common beech is the most widespread species covering approximately 1.915 .600 ha, namely $31 \%$ of the national forest fund (Biriș, 2004; Semeniuc et al., 2014).

Common beech presents a special interest in forestry, being a species with a significant economic and ecologic importance. Besides their economic importance, common beech stands are renowned for their protection functions. This is due to their capacity to balance the hydrologic regime more than any other forest formation, to ensure drinking water with superior qualities, to retain high quantities of dust from the atmosphere, and to consolidate soil against erosion even in the case of weakly productive stands. Furthermore, common beech stands have remarkable ecologic consolidation and self-regulation characteristics being rarely affected by harmful agents (windbreaks, breaks, insect attacks). When mixed with resinous species, they increase their resistance towards windbreaks, contributing to the growth of their productivity and biodiversity (Popescu et al., 2004).

The numerous investigations show that Romania is one of the few European countries that has extended virgin forests such as common beech forests, common beech-fir-Norway spruce forests and oak forests. As such, Stelian 
Radu mentions in his works about Southern Carpathians some multi-secular common beech stands with trees older than 400 years. At the same time, the trees from Nerei Springs are considered amongst the largest natural common beech stands from Europe. Seaca Optășani Forest was declared "forest reservation" in 1969 by the Romanian Academy due to its Hungarian oak stand exemplars and is considered a vestige of sub boreal forests (3000 - 1000 years B.C.) (Radu, 2016). Mândru and his collaborators describe Mociar Forests, located in Nădașa, Mureș County, as the oldest oak forest from Romania, being over 300 years old (Mîndru et al., 2017). Valentin Borlea presents some Romanian forests: Slătioara secular forest from Suceava District aged 350-400; Mociar Forest from Mureş County with 410-year-old pedunculated oak; Goţmanu-Tarcău secular forest from Neamţ County; Strâmbu Băiuţi secular forest with common beech exemplars; Milea-Viforita Forest, Pârâului Negru Forest from O.S. Tarcău, Neamţ County; Niculele virgin forest from O.S. Râmnicu Sărat; and Ronişoara Forest, Maramureş County, with holm renowned in all Europe (Borlea, 2013).

At a worldwide level, Chivulescu has mentioned in his $\mathrm{PhD}$ paper that common beech forests from North America have priority even though they have been extracted in favour of agricultural fields. The most expanded common beech forests from Spain can be found in Navarra, a region from the North-East part, closer to the Pyrenees and occupying over 130.000 hectares, namely $37 \%$ of the country's common beech forests. In addition, 1.4 million hectares of common beech forests can be found in Japan, while Iran has more than 100.000 hectares (Chivulescu, 2017).

The oldest stands from Banatului Mountains can be found in Semenic Mountains as well as in Almajului Mountains. The other massifs from this area (Dognecei Mountains, Locvei Mountains and Aninei Mountains) do not have old stands probably due to the fact that they do not have national parks or virgin forests as in the other mentioned massifs. The most characteristic area for very old stands is Nera which hosts one of the largest natural common beech stands from Europe.

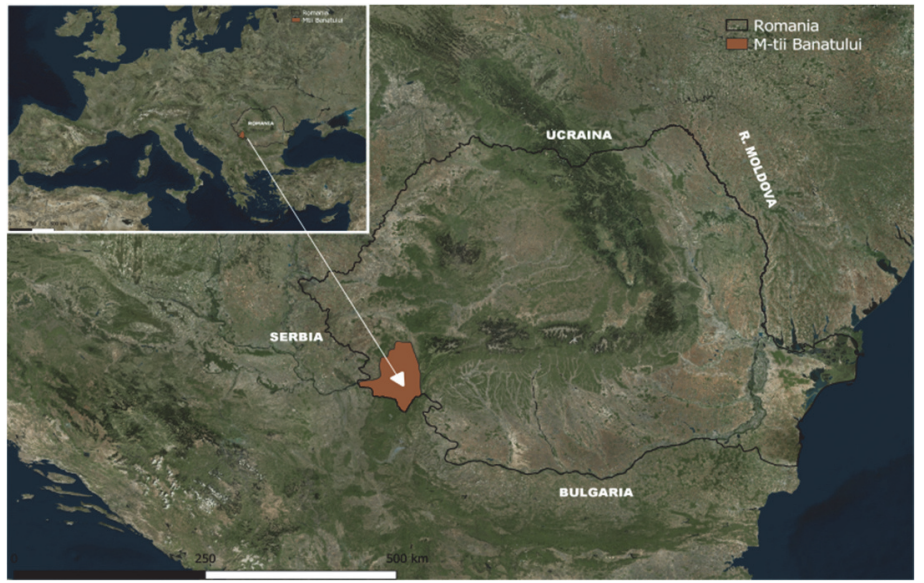

Figure 1. The location of Banatului Mountains. Source: original (Timiș-Gânsac Voichița)

The Banatian Lowlands are characterised by a moderately continental and almost sub-Mediterranean climate. Average temperatures start at $11^{\circ} \mathrm{C}$ while annual precipitations range between 500 and $700 \mathrm{~mm}$. The winters are cold (with an average temperature of $-2^{\circ} \mathrm{C}$ in January), while springs are characterised by rains and the summers are hot (with an average temperature of $22^{\circ} \mathrm{C}$ in July). The climate is more cool and oceanic in the mountains, depending on their elevation (Halbac-Cotoara, 2012; Nitzu et al., 2011; Walter et al., 1975). Due to the fact that Banatului Mountains' elevation is not higher, the high mountain or subalpine areas are not present here (Rösch et al., 2000). Beach (Fagus sylvatica L.) forests are spread at altitudes between $200 \mathrm{~m}$ (Mraconia valley) and 1450 m (the top of Semenic Mountain), (Arsene et al., 2015).

The purpose of this paper was to analyze the main qualitative characteristics of threes (age), the structural characteristics of stands (consistency, composition, average diameter and average height), as well as the stational characteristics (altitude, slope, soil type) and to identify the oldest stands from Banatului Mountains based on data processed from forest management plans.

\section{Methods}

The present study was realized in Banatului Mountains (Romanian Carpathians) and was based on forest management plans realized during 1991- 2008 for forests located in Banatului Mountains (*** Amenajamente silvice) in Nera, Caransebeș and Băile Herculane Forest Districts. All Romanian forests are characterised and 
described at an interval of 10 years through forest management plans.

The following stand and environment characteristics were analyzed in the studied area: age, composition, consistency, exposition, slope, altitude, station type, stand structure and consistency.

The stands' age is determined in these forest management plans (rounded with 5 years) for each stand. The age results from taking into consideration the data from the forest management plans or forest district regarding the year when the regeneration occurred as well as by counting the annual ring from the fresh stumps plus the number of years required to achieve the height of the stem at which the determination is made.

From the extremely large number of data provided (46.600 lines characteristic to stand elements from this area), we have used the ones regarding the oldest stands (aged over 210), namely 394 stand elements. The following site and stand characteristics were analysed by using the Excel program: average diameter and height, stand structure and consistency, field exposition and slope, altitude, types of soils and sites.

\section{Results}

The investigations have shown that state forests from Banatului Mountains occupy 481.718 ha.

The analysis of the existent data has revealed that state forests from Banatului Mountains occupy a surface of 481.718 ha. Stand repartition on age categories of 20 years each (Figure 2) has shown a relatively even distribution with all age categories having similar percentages. However, old stands (with a superior exploitability age - the age at which forests can be cut), over 120 years, occupy a higher surface in this area: 60.978 ha, namely $13 \%$ of the total surface of these forests.

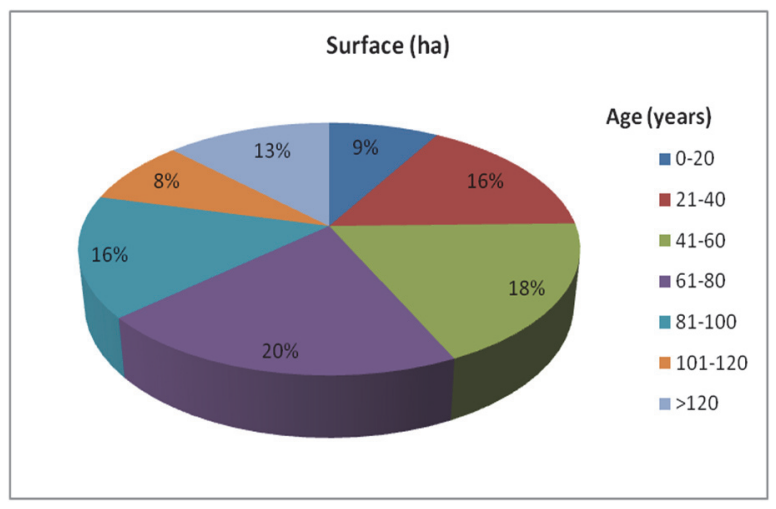

Figure 2. Repartition of stands from Banatului Mountains on age categories

A number of 394 stand elements were identified for stands older than 200 years from Banatului Mountains compared with 86 stand elements from the Southern Carpathians that have the same age (Cântar et al., 2019). As it is normal, the surface occupied by old stands decreases as they get older (figure 3).

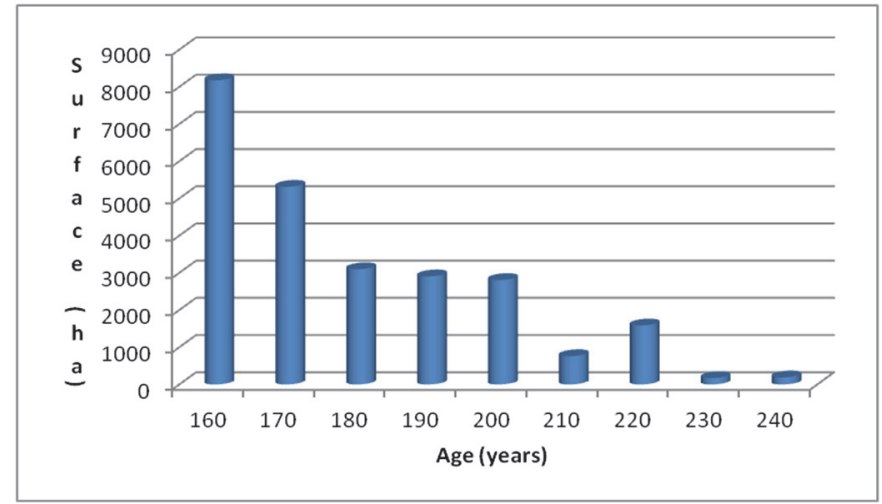

Figure 3. The surface occupied by the oldest stands from Banatului Mountains 
The oldest stand from this area is a common beech stand aged 260 from Nera. This is followed by 12 stands of 255 years and 3 stands of 250 years, all from the same area. Stands of 230 years (37) are spread out mainly in Nera as well as in Caransebes or Baile Herculane. Old stands can also be found in Otelul Rosu, Mehadia and Teregova Forest Districts (figure 4).

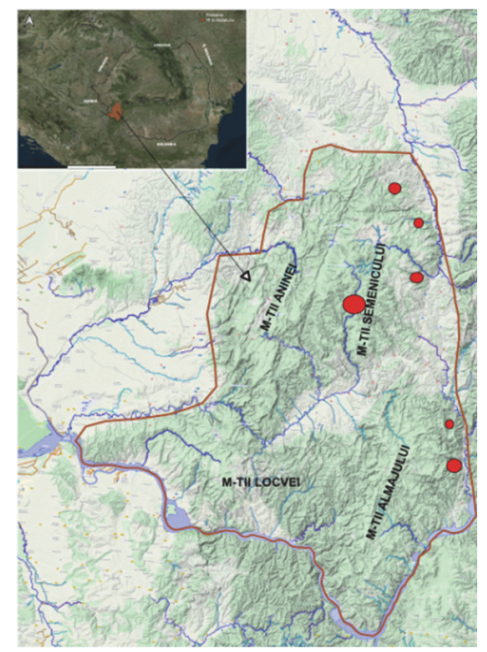

Figure 4. The location of the oldest stands from Banatului Mountains. Source: original (Timiș-Gânsac Voichița)

Table number 1 presents the oldest 18 stands as well as their main characteristics (diameter, height, consistency, slope, altitude, soil, site, structure).

Table 1 The oldest 18 stands from Banatului Mountains

\begin{tabular}{|c|c|c|c|c|c|c|c|c|c|c|c|c|}
\hline Forest District & Species & 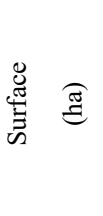 & 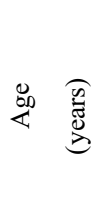 & 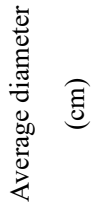 & 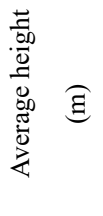 & 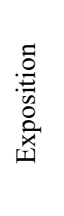 & $\begin{array}{l}\sigma \\
\frac{0}{0} \\
\frac{0}{\omega}\end{array}$ & $\underset{巳}{\stackrel{E}{E}}$ & $\overline{\bar{\delta}}$ & 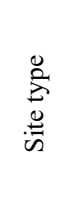 & 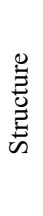 & 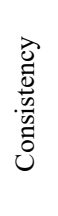 \\
\hline Nera & Common beech & 11.6 & 260 & 98 & 38 & $\mathrm{SE}$ & 28 & 835 & 3301 & 4323 & 3 & 0.5 \\
\hline Nera & Common beech & 10.1 & 255 & 98 & 36 & $\mathrm{E}$ & 45 & 810 & 3301 & 4323 & 3 & 0.8 \\
\hline Nera & Common beech & 18.0 & 255 & 98 & 36 & S & 18 & 930 & 3301 & 4323 & 2 & 0.6 \\
\hline Nera & Common beech & 7.1 & 255 & 98 & 36 & SW & 20 & 930 & 3301 & 4323 & 3 & 0.3 \\
\hline Nera & Common beech & 1.3 & 255 & 98 & 36 & SW & 18 & 930 & 3301 & 4323 & 3 & 0.5 \\
\hline Nera & Common beech & 7.4 & 255 & 98 & 36 & $\mathrm{NE}$ & 10 & 940 & 3301 & 4323 & 2 & 0.9 \\
\hline Nera & Common beech & 16.1 & 255 & 98 & 35 & SW & 20 & 820 & 3301 & 4322 & 3 & 0.8 \\
\hline Nera & Common beech & 10.4 & 255 & 98 & 36 & $\mathrm{E}$ & 35 & 720 & 2401 & 5152 & 3 & 0.8 \\
\hline Nera & Common beech & 18.3 & 255 & 98 & 36 & $\mathrm{E}$ & 38 & 535 & 2401 & 5152 & 3 & 0.8 \\
\hline Nera & Common beech & 26.0 & 255 & 98 & 36 & SE & 32 & 700 & 3301 & 4323 & 3 & 0.8 \\
\hline Nera & Common beech & 19.7 & 255 & 98 & 37 & $\mathrm{NE}$ & 30 & 700 & 3301 & 4323 & 1 & 0.9 \\
\hline Nera & Common beech & 24.7 & 255 & 98 & 37 & $\mathrm{SE}$ & 32 & 870 & 3301 & 4323 & 3 & 0.8 \\
\hline Nera & Common beech & 19.4 & 255 & 98 & 37 & SW & 30 & 690 & 3301 & 4323 & 3 & 0.6 \\
\hline Nera & Common beech & 4.6 & 250 & 96 & 38 & $\mathrm{NE}$ & 31 & 1140 & 3301 & 4323 & 3 & 0.8 \\
\hline Nera & Common beech & 2.8 & 250 & 90 & 38 & SE & 33 & 1090 & 3301 & 4323 & 3 & 0.8 \\
\hline Nera & Common beech & 1.9 & 250 & 92 & 40 & NW & 25 & 985 & 3301 & 4323 & 3 & 0.8 \\
\hline Caransebes & Common beech & 0.5 & 240 & 84 & 33 & S & 33 & 1250 & 3301 & 3323 & 4 & 0.8 \\
\hline
\end{tabular}


The average diameter and height of the oldest stands from this area record very high values. The average diameters of $98 \mathrm{~cm}$ are common for almost all identified stands while characteristic heights range between 36-38 meters (Table 1).

Tree structure is preponderantly relative uneven-age (stands with different ages that exceed 20 years in the case of seed stands and 5 years for sprout ones). Only a very few stands are relative even-aged (stands in which the trees have ages that do not differ with more than 20 years in the case of seed stands and 5 years for sprout ones), even-aged (in which all trees have the same age, originate from the same fructification or from artificial regeneration as well as from sprouts or sucker following a shaving cutting) or uneven-aged (stands with trees of all ages, from seedlings installed after each fructification up to trees that have reached exploitability ages and dimensions in stands cultivated or at the physiological limit from virgin stands). The structure of these stands can be an important criteria for creating smart forests as was recorded in the Southern Carpathians for alder (Blaga et $a l ., 2019$ ) or for Norway spruce (Dincă et al., 2019).

An important structural characteristic of stands was analyzed in this paper, consistency. The investigations have determined that consistency is normal (0.8), with some stands having a very low consistency $(0.3-0.5)$.

From the exposition's point of view, the studied stands have different expositions where the different heath quantity obtained from slopes with varied expositions influence other factors as well, including the plants' physiological processes. The oldest 100 stands are distributed on field exposition on the NE-SW axis (figure 4).

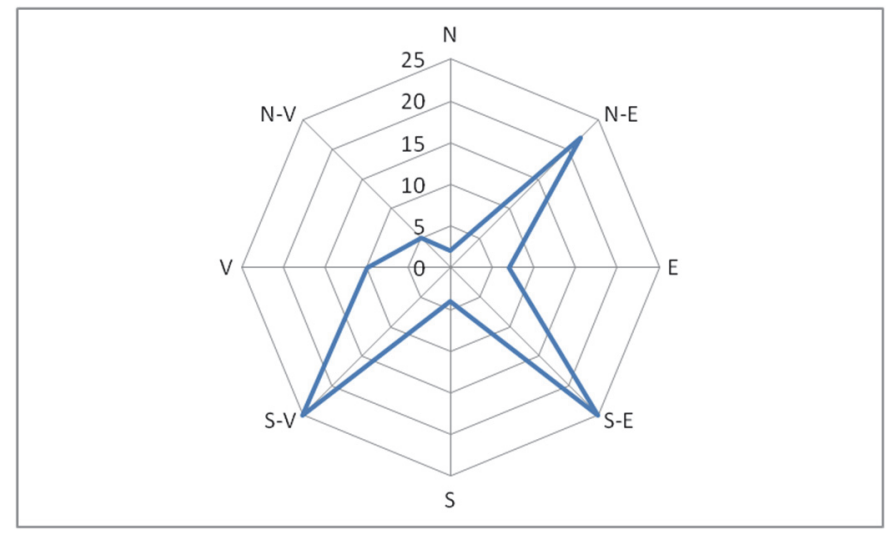

Figure 4. Field exposition for the 100 oldest stands from Banatului Mountains

The most common field slope for the first 100 oldest stands from these mountains is of 21-30 degrees (figure 5).

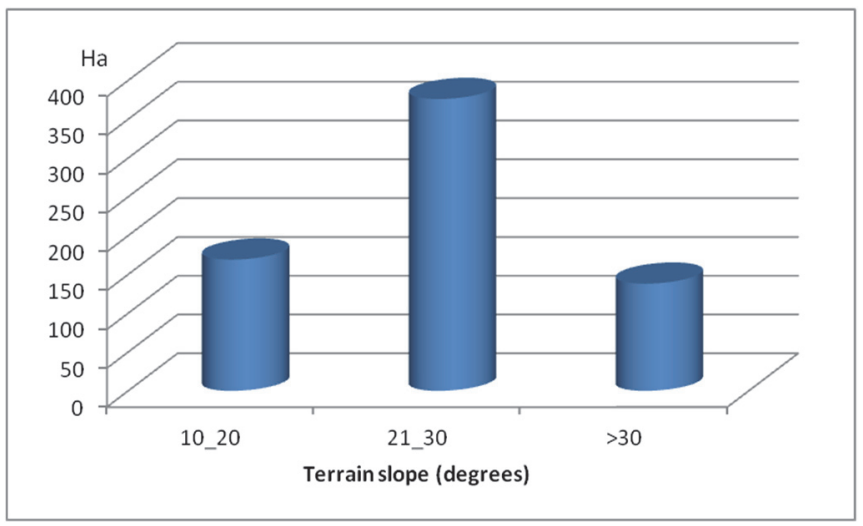

Figure 5. Field slope for the 100 oldest stands from Banatului Mountains

The slope acts closely with the exposition and altitude, influencing as such the environment conditions. As the slope is higher, the percentage of atmospheric precipitations that reaches the soil increases, leading to a decrease 
of soil humidity on inclined slopes compared with smaller slopes. This also leads to landslides and erosion (Dincă et al., 2019).

Common beech (Fagus sylvatica L.) is considered a species specific to temperate and humid climatic conditions, being sensible to drought and manifesting a high degree of vulnerability under climate changes, especially on the South and East limits of this areal (Popa et.al., 2015).

The research concerning common beech has shown that the major limitative factor from the studied areas located at the inferior, South or East altitudinal limit is represented by precipitations (Dittmar et al., 2003; Fotelli et al., 2009; Weber et al., 2013).

Altitude is also present among the analyzed stational characteristics.

Altitude is an important factor in the vegetation's zonal distribution, causing changes in climatic and edaphic factors. Once the altitude grows, the climate becomes colder and more humid which leads to a reduction of the vegetation season. The altitude characteristic for theses stands varies between 900-1000 $\mathrm{m}$ (figure 6).

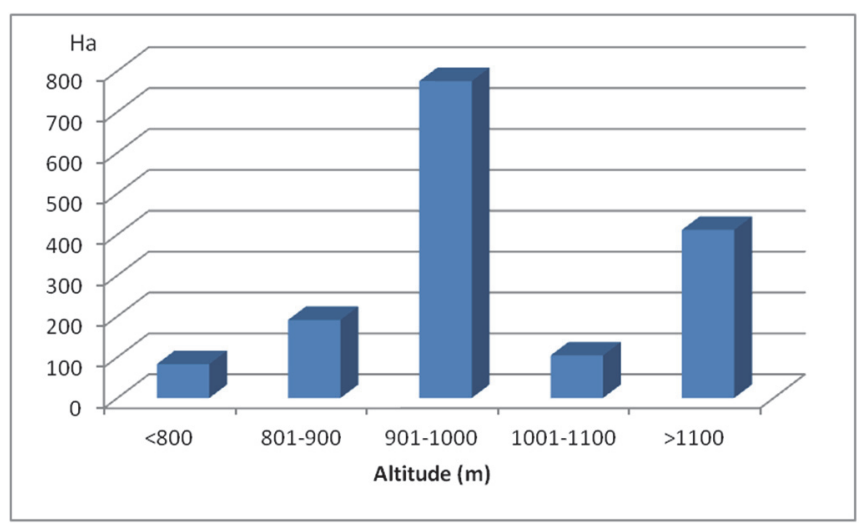

Figure 6. Altitude for the 100 oldest stands from Banatului Mountains

The obtained data have emphasized some important aspects from both a national and international point of view. For example, the most encountered types of soils present in this area are amongst the most widespread soils from Romania (Dincă et al., 2014; Crișan et al, 2017). As such, eutric cambisol and luvisol are well represented at a national level while the results obtained from this study sustain some of their most important attributes that can be further compared with other local or European areas. We mention here their predominance in mountain and premontane areas (Spârchez et al., 2017), their well water supply (Dincă et al., 2018) and their richness in bacteria and microorganism (Onet et al., 2019).

Relevant data were also obtained for the types of sites on which these old stands vegetate. The main types are represented by "Mountain-premontane common beech stands of average reliability, eutric cambisol with average edaphic mull" and Hill holm stands of average reliability, average edaphic preluvisol, eutric cambisol". By comparing these results with other studies, we can observe that the first site type is very similar with site characteristics for the oldest stands located in the Southern Carpathians (Cântar et al., 2019). However, the location influences the results and demonstrate that dystric cambisol soils (which are more acid) are characteristic for the Southern Carpathians, while Banatului Mountains are represented by eutric cambisols.

\section{Conclusions}

The realizes investigations have resulted in identifying 394 stand elements for stands older than 200 years. In addition, the surface occupied by old forests decreases as they advance in ages. Old stands (with an age superior to the exploitability age, meaning the age when they can be cut) of over 120 years occupy a significant surface in this area: 60.978 ha, namely $13 \%$ of the total forest surface from this area.

The oldest stand identified in this location is a common beech stand of 260 years, followed by 12 stands of 255 years and 3 stands of 250 years from Nera Forest District. In addition, 37 stands of 230 years were identified in Nera, Caransebes and Baile Herculane Forest Districts

The oldest stands from this area are characterized by average towards high diameter and heights, by a relatively uneved-aged structure and a normal consistency. They vegetate on fields with predominantly Northeast and 
South-West expositions, with slopes of 21-30 degrees, at an average altitude of 900-1000 m, on eutric cambisol and luvisol and in average and superior reliability sites.These common beech stands from Nera Spring Natural Reservation are considered goods with heritage value both for Romania as well as for the entire Europe.

\section{References}

Amenajamentele silvice ale ocoalelor: Ana Lugojana (1999), Coșava (2002), Oțelul Roșu (2000), Rusca Montană (1991), Caransebeș (1995), Teregova (1992), Mehadia (1993), Băile Herculane (2001), Bocşa Română (2004), Pătliniș (1998), Reșița (2001), Văliug (1992), Oravița (2008), Anina (2007), Nera (2004), Berzeasca (1995), Bocșa Montană (2003), Bozovici (2004), Moldova Nouă (2006), Sasca Montană (2007).

Arsene, G. G., Imbrea, I. M., Nicolin, A. L., \& Neacșu, A. G. (2015). Flora and vegetation of Romanian Banat: an overview. Research Journal of Agricultural Science, 47(3), 3-14.

Biriș, I. A. I. (2014). Făgetele primare din România, o contribuţie la Patrimoniul Mondial UNESCO. Bucovina Forestieră, 14(1), 77-85.

Blaga T., Dincă L., \& Pleșca I. M. (2019). How can smart alder forests (Alnus glutinosa (L.) Gaertn.) from the Southern Carpathians be indentified and managed. Scientific papers series Management, Economic Engineering in Agriculture and Rural Development, 19(4), 29-35.

Borlea, V. (2013). Cele mai frumoase păduri din lume. Revista de Silvicultură și cinegetică, 32, 5-8.

Cântar, I. C., Dincă L., Chisăliță I., Crișan V., \& Kachova V. (2019). Identifying the oldest stands from the Southern Carpathians together with their main characteristics. Proceedings of the Multidisciplinary Conference on Sustainable development, Filodiritto International Proceedings, 186-193.

Chivulescu Ș. M. (2017). Structura și auxologia unor păduri virgine din Munții Semenic, Munții Retezat, Munții Fagaraș si Munții Penteleu. Universitatea Transilvania din Braşov. Teză de doctorat.149 pagini.

Crișan V., \& Dincă L. (2017). The predominant forest soils from Timiș Forest Administration County. JOURNAL of Horticulture, Forestry and Biotechnology, 21(3), 137-141.

Dincă L., \& Achim F. (2019). The management of forests situated on fields susceptible to landslides and erosion from the Southern Carpathians. Scientific papers series Management, Economic Engineering in Agriculture and Rural Development, 19(3), 183-188.

Dincă L., Badea O., Guiman G., Braga C., Crisan V., Greavu V., Murariu G., \& Georgescu L. (2018). Monitoring of soil moisture in Long-Term Ecological Research (LTER) sites of Romanian Carpathians. Annals of Forest Research, 61(2), 171-188. https://doi. 10.15287/afr.2018.1188

Dincă L., Murariu G., Iticescu C., Budeanu M., \& Murariu A. (2019). Norway spruce (Picea Abies (L.) Karst.) smart forests from Southern Carpathians. International Journal of Conservation Science, 10(4), 781-790.

Dincă L., Sparchez G., \& Dincă M. (2014). Romanian’s forest soil GIS map and database and their ecological implications, Carpathian Journal of Earth and Environmental Sciences, 9(2), 133-142.

Dittmar C., Zech W., \& Elling W. (2003). Growth variations of Common beech (Fagus sylvatica L.) under different climatic and environmental conditions in Europe - a dendroecological study. Forest Ecology and Management, 173, 63-78. https://doi.org/10.1016/S0378-1127(01)00816-7

Fotelli M. N., Nahm M., Radoglou K., Rennenberg H., Halyvopoulos G., \& Matzarakis A. (2009). Seasonal and interannual ecophysiological responses of beech (Fagus sylvatica) at its south-eastern distribution limit in Europe. Forest ecology and management, 257, 1157-1164. https://doi.10.1016/j.foreco.2008.11.026

Halbac-Cotoara-Zamfir, R. (2012). The Romanian Banat region challenging climatic changes. Journal of Environmental Protection and Ecology, 13(1), 128-134.

Mîndru M., Păcurar I., Roșca S., \& Bilașco Ș. (2017). Forest Favorability in Mociar Forest, Romania. ProEnvironment, 10, 115-125.

Nitzu, E. N., Popa, I., \& Giurginca, A. (2011). Invertebrate fauna (Coleoptera, Collembola, Diplopoda, Isopoda) collected in the karst areas of the Aninei-Locvei Mountains. Travaux de lInstitute de Spéologie Émile Racovitza, 50, 15-35.

Onet A., Dincă L. C., Grenni P., Laslo V., Teusdea A. C., Vasile D. L., Enescu R. E., \& Crisan, V. E. (2019). Biological indicators for evaluating soil quality improvement in a soil degraded by erosion processes, Journal of Soils and Sediments, 19(5), 2393-2404. https://doi.org/10.1007/s11368-018-02236-9

Popa, I., \& Caisîn V. (2015). Răspunsul comparativ al fagului şi stejarului la secetă în Rezervaţia Naturală Codrii 
(R. Moldova). Bucovina Forestieră, 15(1), 45-53.

Popescu, Gh., \& Pătrăşcoiu, N. (2004). Pădurea şi omul. Editura Nord Carta, Suceava.

Rösch, M., \& Fischer, E. (2000). A radiocarbon dated Holocene pollen profile from the Banat mountains (Southwestern Carpathians, Romania). Flora, 195(3), 277-286. https://doi.org/10.1016/S0367-2530(17)30981-7

Semeniuc, A., Popa, I., Timofte, A. I., \& Gurean, D. M. (2014). Xylem phenology of Fagus sylvatica in Rarău mountains (Eastern Carpathians. Romania). Notulae Botanicae Horti Agrobotanici, 42, $275-279$. https://doi.org/10.15835/nbha4219546

Spârchez G., Dincă L., Marin G., Dincă M., \& Enescu R.E. (2017). Variation of eutric cambisols' chemical properties based on altitudinal and geomorphological zoning. Environmental Engineering and Management Journal, 16(12), 29-35.

Stelian R. (2016). Pădurile României - semnale din străinătate. Revista Pădurilor. Anul XXI, Nr. 39, 13-15.

Swetnam, T. W., \& Brown, P. M. (1992). Oldest known conifers in the southwestern United States: temporal and spatial patterns of maximum age. Old Growth Forests in the Southwest and Rocky Mountain Regions. USDA Forest Service General Technical Report RM-213, 24-38.

Walter, H., Harnickell, E., \& Mueller-Dombois, D. (1975). Klimadiagramm-Karten der einzelnen Kontinente und die ökologische Klimagliederung der Erde; eine Erganzung $\mathrm{zu}$ de Vegetationsmonographien. Vegetationsmonographien der einzelnen Grossraume.

Weber P., Bugmann H., Pluess A.R., Walthert L., \& Rigling A., (2013). Drought response and changing mean sensitivity of European beech close to the dry distribution limit. Trees, 27, 171-181. https://doi.org/10.1007/s00468-012-0786-4

\section{Copyrights}

Copyright for this article is retained by the author(s), with first publication rights granted to the journal.

This is an open-access article distributed under the terms and conditions of the Creative Commons Attribution license (http://creativecommons.org/licenses/by/4.0/). 